\title{
Экономическая дОступность продовольствия в контексте проведения политики протекционизма ${ }^{1}$
}

В.C. КонкИнА, кандидат экономических наук, Рязанский государственный агротехнологический университет имени П. А. Костычева, Рязань. E-mail: Konkina_v@mail.ru

Аннотация. В статье рассматривается один из аспектов продовольственной безопасности при реализации политики протекционизма в агропродовольственной сфере. Проведен анализ доступности продовольствия в разрезе децильных групп. Отмечается отсутствие серьезных улучшений в динамике показателя за пять лет. Сокращение импорта и отсутствие внешней конкуренции способствовали росту цен на продовольственные товары на внутреннем рынке. Данные факторы при одновременном снижении реальных доходов привели к негативным последствиям - повысили планку экономической доступности продовольствия для домохозяйств.

Ключевые слова: продовольствие; экономическая доступность; децильные группы; импортозамещение; продовольственная безопасность

Проблемы импортозамещения с 2014 г. занимают умы не только научного сообщества, но и российской номенклатуры. Введение продовольственного эмбарго обусловило необходимость оперативного решения основной цели - обеспечения продовольственной безопасности и реализации целой совокупности дополнительных мер - протекционизм национального АПК, ускоренная модернизация сектора и т.д. К сожалению, как показало дальнейшее развитие событий, продовольственная безопасность зачастую понимается в узком смысле - как сокращение доли импорта в ресурсах до некоего «безопасного» уровня. О необходимости обеспечения физической и экономической доступности продовольствия для населения в высших эшелонах власти, в научном и даже общественном дискурсе речь заходит очень редко.

${ }^{1}$ Статья подготовлена при финансовой поддержке РФФИ, проект № 18-010-00843. 
Последовательная политика по защите российского продовольственного рынка от внешней конкуренции, подкрепленная значительной государственной поддержкой, привела к позитивным результатам. Выросло производство продовольствия, Россия вошла в тройку главных экспортеров зерна, индикаторы Доктрины продовольственной безопасности ${ }^{2}$ достигнуты практически по всем видам сельскохозяйственной продукции. Но как это отражается на экономической доступности продовольствия? Темпы роста цен на продовольствие опережают уровень инфляции, реальные доходы домашних хозяйств снижаются с 2014 г., а доля расходов на продукты питания, напротив, растет. Анализ данных процессов в разрезе отдельных групп домохозяйств вскрывает крайне тревожные тренды в развитии ситуации. Как оценивать уровень продовольственной безопасности в России при таких противоречивых данных? Попробуем разобраться.

\section{Падение спроса и снижение потребления на рынке продовольствия}

Четыре года действия запретительных мер позволяют сделать предварительные выводы об интенсивности процессов импортозамещения в агропродовольственной сфере России и выполнении Доктрины продовольственной безопасности. На наш взгляд, анализ продовольственной безопасности в РФ следует проводить в контексте понятийного симбиоза - оценки масштабов производства сельскохозяйственной продукции и ее доступности для населения.

Качественные, количественные и структурные характеристики производства и потребления продуктов питания определяются совокупностью факторов, среди которых можно выделить следующие:

- объемы и структура собственного производства;

- объемы и структура экспорта и импорта;

- ценовая конъюнктура на мировом и национальном продовольственных рынках;

\footnotetext{
${ }^{2}$ Указ Президента Российской Федерации от 30 января 2010 г. № 120 «Об утверждении Доктрины продовольственной безопасности Российской Федерации» [Эл.ресурс]. URL: http://base.garant.ru/12172719/ (дата обращения: 10.12. 2018).
} 
- покупательная и покупательская способность доходов населения ${ }^{3}$ и др.

Обратная связь факторов «производство - импорт» и прямая - «производство - экспорт» бесспорна и подтверждается успехами отечественного сельского хозяйства. Опорой такой связи является весьма щедрая государственная поддержка ${ }^{4}$. Однако с точки зрения формирования платежеспособного спроса результаты агропродовольственной политики, реализуемой Минсельхозом и Правительством РФ, неоднозначны и неочевидны. Спустя четыре года после начала ее реализации мы наблюдаем рост цен, падение платежеспособного спроса и снижение уровня жизни населения (особенно с невысокими доходами).

Отметим, что в мировой истории можно найти немало примеров тому, как введение запретительных мер ведет к росту цен, повышению издержек производителей, сокращению спроса и в конце концов - падению эффективности защищаемых секторов.

Динамика спроса на продукты питания и объемов их потребления зависит от соотношения темпов изменения реальных доходов и цен на продовольственные товары. Значительные отклонения между этими показателями порождают риски утраты продовольственной безопасности.

Чтобы оценить уровень экономической доступности основных товаров продовольственной корзины, мы рассчитали для них коэффициент достаточности (табл. 1).

\footnotetext{
${ }^{3}$ Следует различать два этих понятия. Покупательная способность - экономический показатель, обратно пропорциональный количеству валюты, необходимой для покрытия определенной потребительной корзины товаров и услуг. Покупательская способностькритерий, показывающий, сколько может купить среднестатистический потребитель товаров и услуг на определенную сумму денежных средств при нынешнем уровне цен. Таким образом, первое понятие относится к свойствам денег, а второе - к самим покупателям Покупательная способность рубля, но покупательские предпочтения. [Эл. pecypc]. URL: http://postcard-money.com/kak-pravilno-pokupatelnaya-ili-pokupatelskayasposobnost.html (дата обращения: 13.04.2019).

${ }^{4}$ По данным Минсельхоза РФ, с учетом предварительных решений в 2019 г. объем средств федерального бюджета на реализацию госпрограммы АПК составит 302,2 млрд руб. При этом, как ранее обещал премьер-министр Д. Медведев на открытии «Золотой осени», «мы сохраним все инструменты, меры поддержки, объемы финансирования, которые в настоящий момент имеются» (цитата по стенограмме на government.ru). [Эл.pecypc]. URL: https://www.ryazagro.ru/news/11746/ (дата обращения: 11.01.2019).
} 
Таблица 1. Динамика коэффициента достаточности основных видов продовольствия* для населения РФ в 2012-2017 гг.

\begin{tabular}{|l|c|c|c|c|c|c|}
\hline \multicolumn{1}{|c|}{ Вид продукции } & $\mathbf{2 0 1 2}$ & $\mathbf{2 0 1 3}$ & $\mathbf{2 0 1 4}$ & $\mathbf{2 0 1 5}$ & $\mathbf{2 0 1 6}$ & $\mathbf{2 0 1 7}$ \\
\hline Картофель & 1,233 & 1,233 & 1,233 & 1,244 & 1,256 & 1,067 \\
\hline Молоко & 0,766 & 0,763 & 0,751 & 0,735 & 0,726 & 0,711 \\
\hline Мясо и мясопродукты & 0,932 & 0,945 & 0,945 & 0,918 & 0,932 & 1,027 \\
\hline Овощи & 0,779 & 0,779 & 0,793 & 0,793 & 0,800 & 0,800 \\
\hline Фрукты и ягоды & 0,610 & 0,640 & 0,640 & 0,610 & 0,620 & 0,620 \\
\hline Хлеб и хлебные продукты & 1,240 & 1,229 & 1,229 & 1,229 & 1,219 & 1,219 \\
\hline Яйца & 1,062 & 1,035 & 1,035 & 1,035 & 1,050 & 1,058 \\
\hline
\end{tabular}

* Определяется как отношение фактического объема потребления конкретного вида продукции к рациональным нормам потребления пищевых продуктов, отвечающих современным требованиям здорового питания 5 .

Источник табл. 1, 2, 4-6, рис. 1-3: Основные показатели сельского хозяйства в России [Эл. ресурc]. URL: http://www.gks.ru (дата обращения: 05.09.2018). Расчеты автора.

Казалось бы, представленные данные показывают, что за 2012-2017 гг. уровень доступности основных продуктов продовольствия не претерпел серьезных изменений. По мясу, мясопродуктам и яйцам показатель даже немного увеличился в 2017 г. относительно 2012 г. В то время как по картофелю, молоку и хлебу он незначительно сократился. Однако углубленный анализ статистических показателей заставляет сделать выводы, далекие от оптимизма.

\section{Снижение реальных доходов и доступности продовольствия}

Известно, что мотивация потребителей к тратам связана с размером получаемого/располагаемого ими дохода (хотя, как указывали классики - Дж. М. Кейнс, Э. Гиффен, - между темпами изменения доходов и объемами потребления нет четкой пропорциональной зависимости).

Как показывает макроэкономическая статистика, до 2014 г., когда были введены запретительные меры, реальные доходы домашних хозяйств в целом по РФ росли, «увлекая» за собой и их расходы (в 2014 г. они достигли максимума - более 53\% от ВВП). Далее наблюдается планомерное снижение расходов,

\footnotetext{
${ }_{5}^{5}$ Приказ Министерства здравоохранения РФ № 614 от 19 августа 2016 г. «Рекомендации по рациональным нормам потребления пищевых продуктов, отвечающих современным требованиям здорового питания».
} 
обусловленное в первую очередь снижением реальных доходов населения (2015 г. - 52\% от ВВП, 2016 г. - 52,8\%, 2017 г. 52,2\%). По данным Росстата, реальные располагаемые денежные доходы населения составили в 2015 г. - 96,8\%, 2016 г. - 94,2\%, 2017 г. - 98,3\% (в сравнении с предыдущим годом) ${ }^{6}$. Прогноз на 2019 г. также неблагоприятный. Согласно экспертным оценкам управляющего партнера экспертной группы Veta Ильи Жарского, - «растущие налоги... прибьют к полу потребительские расходы, а повышение пенсионного возраста еще больше их сократит» ${ }^{7}$.

Динамика потребления продуктов питания в натуральном выражении в целом повторяет динамику реальных доходов и платежеспособного спроса (табл. 2).

Таблица 2. Динамика среднедушевого потребления основных видов продуктов питания в РФ, 2012-2017 гг., кг/год

\begin{tabular}{|l|c|c|c|c|c|c|c|}
\hline Вид продуктов питания & $\mathbf{2 0 1 2}$ & $\mathbf{2 0 1 3}$ & $\mathbf{2 0 1 4}$ & $\mathbf{2 0 1 5}$ & $\mathbf{2 0 1 6}$ & $\mathbf{2 0 1 7}$ & $\begin{array}{c}\mathbf{2 0 1 7} \text { г. в \% } \\
\text { к 2012 г. }\end{array}$ \\
\hline Картофель & 111 & 111 & 111 & 112 & 113 & 1,067 & 86,49 \\
\hline Молоко & 249 & 248 & 244 & 239 & 236 & 0,711 & 92,77 \\
\hline Мясо и мясопродукты & 68 & 69 & 69 & 67 & 68 & 1,027 & 110,29 \\
\hline Овощи & 109 & 109 & 111 & 111 & 112 & 0,764 & 98,17 \\
\hline Фрукты и ягоды & 61 & 64 & 64 & 61 & 62 & 0,590 & 96,72 \\
\hline Хлеб и хлебные продукты & 119 & 118 & 118 & 118 & 117 & 1,219 & 98,32 \\
\hline Яйца, шт./год & 276 & 269 & 269 & 269 & 273 & 1,073 & 101,09 \\
\hline
\end{tabular}

Наиболее благополучными с точки зрения потребления были 2012-2013 гг. После введения продуктового эмбарго в 2014 г. удельное потребление сократилось. Небольшое оживление фиксируется только в 2017 г., но только по отдельным продовольственным группам - яйцам, мясу и мясопродуктам.

При этом нужно обратить внимание, что по всем номенклатурным позициям фактическое потребление не соответствует установленным минимально-рекомендуемым медицинским нормам $^{8}$ (табл. 3).

${ }^{6}$ URL: http://www.gks.ru/wps/wcm/connect/rosstat_main/rosstat/ru/statistics/population/ level/\#

${ }^{7}$ URL: https://www.yandex.ru/turbo?text=http\%3 A\%2F\%2Fwww. ng.ru\%2Feconomics\%2F2018-11-08\%2F4_7348_korzina.html

${ }^{8}$ Приказ Министерства здравоохранения РФ № 614 от 19 августа 2016 г. «Рекомендации по рациональным нормам потребления пищевых продуктов, отвечающих современным требованиям здорового питания». 


\section{Таблица 3. Рекомендуемые рациональные нормы потребления пищевых продуктов, отвечающих современным требованиям здорового питания человека}

\begin{tabular}{|l|c|}
\hline \multicolumn{1}{|c|}{ Наименование продукта } & Кг/год \\
\hline $\begin{array}{l}\text { Хлебные продукты (хлеб и макаронные изделия в пересчете на муку, мука, крупы, } \\
\text { бобовые) }\end{array}$ & 96 \\
\hline Картофель & 90 \\
\hline Овощи и бахчевые & 140 \\
\hline Фрукты свежие & 100 \\
\hline Сахар & 24 \\
\hline Мясопродукты & 73 \\
\hline Рыбопродукты & 22 \\
\hline Молоко и молокопродукты, всего в пересчете на молоко & 325 \\
\hline Яйца, шт. & 260 \\
\hline Масло растительное & 12 \\
\hline
\end{tabular}

Получается, что, несмотря на «достаточность» продовольственного снабжения (таблица 1), рацион питания населения РФ недостаточно сбалансирован с точки зрения поддержания удовлетворительного уровня жизни и здоровья.

Отметим, что представленная выше статистика демонстрирует обратно-пропорциональную зависимость уровня удовлетворения потребности в продуктах питания и эластичности спроса на них. В соответствии с законом Гиффена, низкая насыщенность рынка по конкретной товарной позиции формирует на нее высокочувствительный спрос по доходам, и наоборот.

Вместе с тем, влияние динамики доходов на спрос и потребление продовольствия неоднозначно. В том числе потому, что продукты питания имеют четко очерченный предел насыщения.

Например, в некоторых случаях при росте доходов спрос, измеренный в абсолютных единицах, может расти, а в относительных (удельный вес в совокупных расходах) - уменьшаться. Такое происходит, если эластичность спроса на продовольствие будет уменьшаться по сравнению с эластичностью спроса на непродовольственные товары. С другой стороны, по инфериорным товарам, к которым относятся многие продукты питания (макароны, мучные изделия, крупы) спрос имеет тенденцию к увеличению даже при уменьшении реальных доходов.

В этом смысле то, что среднедушевое потребление базовых продуктов питания падает, несмотря на то, что его объемы далеки от минимально-рекомендуемых норм, не может не настораживать. 


\section{Доступность продовольствия в разрезе групп домашних хозяйств}

Еще один важный момент, на который нужно обратить внимание при анализе таблиц 1 и 2 - это то, что в них используются усредненные показатели по РФ, не позволяющие учесть широкое социальное расслоение общества.

Для более четкого представления о текущей ситуации с реальными доходами и покупательской способностью, проведем анализ в разрезе децильных групп ${ }^{9}$. Соответствующее изменение доходов населения представлено на рисунке 1.

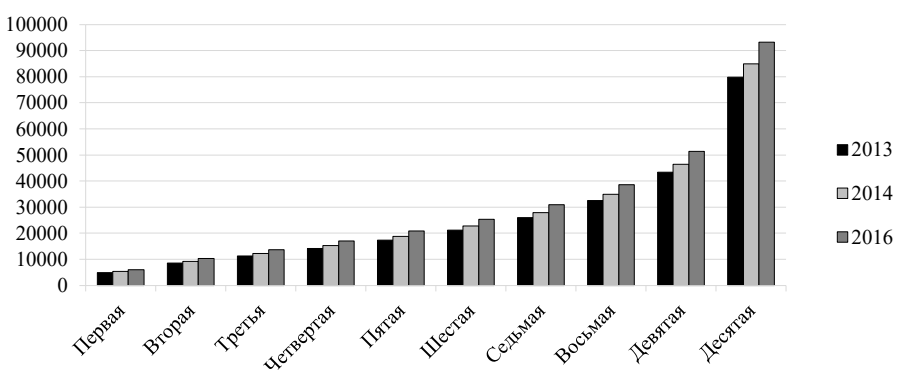

Puc. 1. Динамика доходов населения в разрезе децильных групп за 2013-2016 гг., руб.

В 2013 г. доходы десятой группы превышали аналогичный показатель первой группы в 16,35 раза, затем разница стала сокращаться и к 2015 г. достигла отметки 15,58 раза. С 2016 г. разрыв в доходах снова начал расти.

По состоянию на 2017 г. первые восемь децильных групп, составляющих «львиную» долю населения (80\%), имели доход, не превышающий 40 тыс. руб. в месяц на душу члена домашнего хозяйства. Тогда как доходы в десятом дециле составляют

\footnotetext{
${ }^{9}$ При построении группировок по децильным группам применяется порядок, в соответствии с которым взвешенные данные по числу лиц в домохозяйствах ранжируются по мере возрастания среднедушевых показателей благосостояния и суммируются нарастающим итогом с получением общего числа обследуемого населения. Эта численность принимается за 100\%. Сумма всех домохозяйств, где сосредоточено по $10 \%$ от общего числа обследуемого населения, относится к соответствующей децильной группе населения, распределенного по мере роста показателей благосостояния. Первая децильная группа-с наименьшими доходами, десятая - с наибольшими.
} 
в среднем 94 тыс. руб. В стране 13,2\% населения имеют доходы ниже прожиточного минимума.

Доля расходов на питание отличается как по децильным группам, так и по годам (табл. 4).

Таблица 4. Доля расходов на питание в доходах домашних хозяйств по децильным группам, 2013-2017 гг., \%

\begin{tabular}{|l|c|c|c|c|c|}
\hline Децильная группа & $\mathbf{2 0 1 3}$ & $\mathbf{2 0 1 4}$ & $\mathbf{2 0 1 5}$ & $\mathbf{2 0 1 6}$ & $\mathbf{2 0 1 7}$ \\
\hline Первая & 41,8 & 42,7 & 42,3 & 46,6 & 48,1 \\
\hline Вторая & 40,4 & 40,4 & 41,3 & 43,3 & 45,3 \\
\hline Третья & 38,7 & 38,6 & 39,9 & 42,9 & 44,1 \\
\hline Четвертая & 36,6 & 36,6 & 38,9 & 40,6 & 41,3 \\
\hline Пятая & 35 & 35,2 & 37,3 & 38,8 & 39,1 \\
\hline Шестая & 32,5 & 33,7 & 34,8 & 36,3 & 37,3 \\
\hline Седьмая & 28,7 & 30 & 31,9 & 33,6 & 35,3 \\
\hline Восьмая & 24,8 & 26,9 & 29,3 & 30,7 & 32,3 \\
\hline Девятая & 21,5 & 23,5 & 26,8 & 27,3 & 28,3 \\
\hline Десятая & 14,8 & 14,9 & 19,4 & 18,6 & 18,4 \\
\hline В среднем & 26,2 & 27 & 30,3 & 30,5 & 37,0 \\
\hline
\end{tabular}

Как видим, беднейшие домохозяйства регулярно тратят на продовольствие более $40 \%$ своего бюджета (2013 г. - 41,8\%, 2017 г. - 48,1\%), а члены группы с самыми высокими доходами - не более 20\% (2013 г. - 14,8\%, 2017 г. - 18,4\%). Еще более разительным выглядит разрыв в абсолютных цифрах: в 2017 г. расходы на питание в первой децильной группе составляли 2893,22 руб./месяц на члена семьи, а в десятой - 17400,14 руб. [Бикеева, 2018].

Отчасти рост доли расходов на питание обусловлен удорожанием продовольствия (табл. 5). Проведенный расчет продуктовой инфляции показал, что самыми сложными периодами были 2014 и 2015 гг., когда отмечался наибольший рост цен. На наш взгляд, это во многом было обусловлено введением продовольственного эмбарго - низкая продовольственная обеспеченность практически по всем номенклатурным позициям и отсутствие отработанной логистики по замещающему импорту товаров привели к предсказуемым результатам.

Эксперты Института экономической политики имени Е. Гайдара, РАНХиГС и Всероссийской академии внешней торговли подсчитали, что в 2014-2016 гг.из-за продовольственного эмбарго российские потребители ежегодно теряли 4380 руб. на душу члена 
домашнего хозяйства [Шагайда и др., 2016]. По их расчетам, без санкций стоимость набора запрещенных к ввозу товаров (мяса и мясной продукции, молока и молочной продукции, рыбы, овощей, фруктов, орехов из США, Евросоюза, Норвегии, Австралии и Канады. Позднее в перечень стран были добавлены Албания, Черногория, Исландия, Лихтенштейн, Украина) в 2017 г. была бы ниже примерно на 3\%, а несанкционных - на 2,9\%. Средний прирост годовой инфляции за счет введения санкций эксперты оценили в 3,1 п.П. в обеих категориях [Гайсин, 2018].

\section{Таблица 5. Динамика индексов потребительских цен и цен на от- дельные группы и виды продовольственных товаров в 2013-2017 rг., \%}

\begin{tabular}{|l|c|c|c|c|c|}
\hline \multicolumn{1}{|c|}{ Наименование продукта } & $\mathbf{2 0 1 3}$ & $\mathbf{2 0 1 4}$ & $\mathbf{2 0 1 5}$ & $\mathbf{2 0 1 6}$ & $\mathbf{2 0 1 7}$ \\
\hline Продукты питания в целом & 106,2 & 116,7 & 114,3 & 103,9 & 100,7 \\
\hline Хлебобулочные изделия и крупы & 106,4 & 111,6 & 115,3 & 105,6 & 100 \\
\hline Картофель & 143,9 & 115,2 & 74,3 & 100,1 & 111,2 \\
\hline Мясо & 100,3 & 119,3 & 107,8 & 102,6 & 99,9 \\
\hline Молочные изделия, сыр и яйца & 103,7 & 116,3 & 114,2 & 110,5 & 102,7 \\
\hline Рыба и морепродукты & 102,8 & 107 & 118 & 122,9 & 103,3 \\
\hline Овощи & 118,8 & 118,7 & 108 & 92,3 & 102,3 \\
\hline Фрукты & 99,7 & 123,7 & 128,7 & 96 & 100 \\
\hline Сахар & 102,6 & 140 & 112,9 & 94 & 96,5 \\
\hline Масла и жиры & 108,4 & 110,6 & 122,2 & 113 & 102,4 \\
\hline
\end{tabular}

Таким образом, введение продовольственного эмбарго дало возможность российским производителям и торговле поднять цены в условиях временного ограничения поставок [Шагайда, Узун, 2015]. Интенсификация процессов импортозамещения постепенно привела к стабилизации индексов потребительских цен с 2016 г. В 2017 г. по таким видам продукции, как сахар, фрукты и мясо, наблюдаются даже дефляционные тенденции.

Помимо разрыва количественных показателей (доля расходов на питание), углубление дифференциации между децильными группами отмечается по качественным характеристикам (составу потребительской корзины). Для целей нашего исследования мы проанализировали потребление основных продуктов питания по каждой децильной группе.

Расчеты показали, что рацион россиян за исследуемый период заметно изменился. Продуктовое эмбарго и как результат значительный рост цен на продовольствие привели в 2014-2015 гг. 
к ухудшению рациона питания. Несмотря на то, что в 20162017 гг. ситуация стабилизировалась, рацион первой социальной группы с точки зрения диетологии остается скудным. По таким ценным продуктам, как молоко, мясо, фрукты и овощи, фактическое потребление вдвое отстает от рекомендуемых медициной норм. Лишь по «продуктам бедняков» (картофель, хлеб, мясо птицы) потребление приближается к нормативам. В десятой децильной группе рационы в целом более сбалансированы, при этом по каждой децильной группе наблюдается недостаток белков, фруктов и ягод (табл. 6).

Таблица 6. Пищевая и энергетическая ценность продуктов питания (в том числе в продуктах животного происхождения) по децильным группам в 2017 г., г в сутки

\begin{tabular}{|l|c|c|c|c|c|c|c|c|c|c|c|}
\hline Показатель & $\begin{array}{c}\text { Нор- } \\
\text { ма* }\end{array}$ & $\begin{array}{c}\text { Пер- } \\
\text { вая }\end{array}$ & $\begin{array}{c}\text { Вто- } \\
\text { рая }\end{array}$ & $\begin{array}{c}\text { Тре- } \\
\text { тья }\end{array}$ & $\begin{array}{c}\text { Чет- } \\
\text { вер- } \\
\text { тая }\end{array}$ & $\begin{array}{c}\text { Пя- } \\
\text { тая }\end{array}$ & $\begin{array}{c}\text { Ше- } \\
\text { стая }\end{array}$ & $\begin{array}{c}\text { Седь- } \\
\text { мая }\end{array}$ & $\begin{array}{c}\text { Вось- } \\
\text { мая }\end{array}$ & $\begin{array}{c}\text { Де- } \\
\text { вя- } \\
\text { тая }\end{array}$ & $\begin{array}{c}\text { Де- } \\
\text { ся- } \\
\text { тая }\end{array}$ \\
\hline $\begin{array}{l}\text { Пищевая } \\
\text { ценность }\end{array}$ & & & & & & & & & & & \\
\hline \multirow{2}{*}{ белки } & 102 & 59 & 67 & 73 & 77 & 78 & 81 & 85 & 90 & 92 & 93 \\
& $(51)$ & $(32)$ & $(40)$ & $(44)$ & $(47)$ & $(49)$ & $(51)$ & $(55)$ & $(59)$ & $(62)$ & $(63)$ \\
\hline \multirow{2}{*}{ жиры } & 128 & 75 & 89 & 98 & 104 & 107 & 110 & 117 & 123 & 127 & 128 \\
& $(90)$ & $(43)$ & $(53)$ & $(60)$ & $(64)$ & $(67)$ & $(70)$ & $(75)$ & $(80)$ & $(84)$ & $(85)$ \\
\hline \multirow{2}{*}{ углеводы } & 586 & 288 & 309 & 326 & 335 & 335 & 340 & 351 & 362 & 364 & 361 \\
& $(23)$ & $(10)$ & $(12)$ & $(14)$ & $(15)$ & $(16)$ & $(16)$ & $(17)$ & $(18)$ & $(19)$ & $(19)$ \\
\hline
\end{tabular}

* MP 2.3.1.2432-08 Нормы физиологических потребностей в энергии и пищевых веществах для различных групп населения Российской Федерации [Эл. ресурс]. URL: http://docs.cntd.ru/document/1200076084

\section{Анализ процессов импортозамещения для поиска резервов роста внутреннего спроса на продовольствие}

Для активизации процессов импортозамещения и повышения экономической доступности продовольствия актуальной задачей является формирование внутреннего платежеспособного спроса. При этом, как показал анализ, в нашей стране формирование устойчивого платежеспособного спроса на продукты питания сдерживается не только и не столько открытыми и доказанными Энгелем и Кейнсом закономерностями роста спроса и падения эластичности в условиях повышения степени удовлетворения потребностей населения, сколько внутрироссийскими особенностями, к которым относятся: 
- низкий уровень доходов у подавляющего большинства населения;

- высокая социальная дифференциация общества.

Влияние этих факторов приводит к тому, что реальный спрос (потребление) по основным продуктовым группам практически у всех децилей нельзя признать достаточным - либо по количеству, либо по структуре, либо по тому и другому. Наибольшую озабоченность вызывает ситуация, сложившаяся в первых децильных группах, в которых перекос отмечается одновременно по двум параметрам.

Основная причина этого - низкие реальные доходы. Самое неприятное, что их статистика отчетливо демонстрирует понижающий тренд, и это не позволяет сформировать позитивный прогноз относительно перспектив продовольственной обеспеченности (рис. 2).

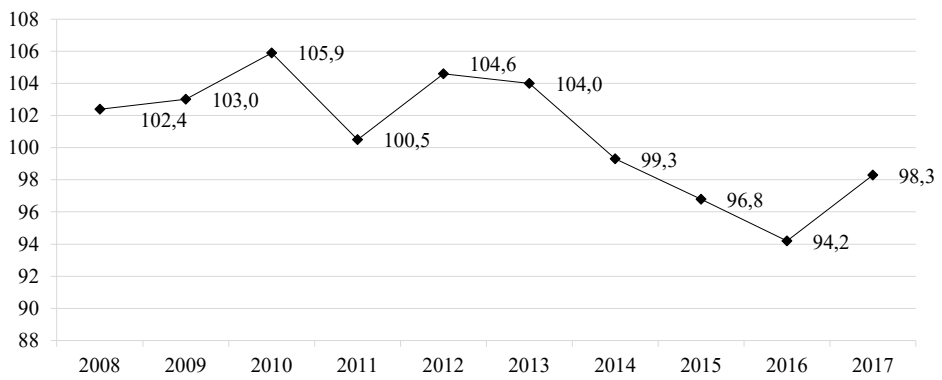

Pис. 2. Динамика реальных доходов населения РФ в 2008-2017 гг.,\%

Предложение на агропродовольственном рынке может расти высокими темпами за счет таких факторов, как высокий ресурсный потенциал, введенные заградительные меры (продовольственное эмбарго) и щедрая государственная поддержка. Но даже при наличии таких преференций без увеличения реального спроса потенциал АПК в области процессов импортозамещения не может быть реализован в полной мере.

Как результат, в отечественном агропромышленном комплексе формируется конъюнктура, которую можно описать как кризис относительного недопроизводства (рис. 3) (ситуация, когда спрос на сельскохозяйственную продукцию обгоняет ее предложение). 


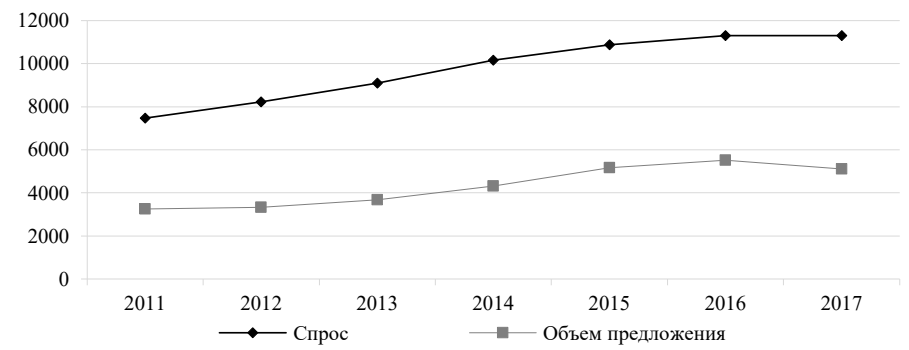

Puc. 3. Динамика изменения спроса и предложения на сельскохозяйственную продукцию в 2011-2017 гг., млрд руб.

Диспаритет цен, государственное регулирование ценообразования в агропромышленном комплексе приводят к занижению доходности сельхозтоваропроизводителей (табл. 7).

Таблица 7. Индексы цен и рентабельность продукции сельского хозяйства и промышленную продукцию и услуги, потребляемые в сельском хозяйстве в 2013-2017 гг., \%

\begin{tabular}{|l|c|c|c|c|c|}
\hline \multicolumn{1}{|c|}{ Показатель } & $\mathbf{2 0 1 3}$ & $\mathbf{2 0 1 4}$ & $\mathbf{2 0 1 5}$ & $\mathbf{2 0 1 6}$ & $\mathbf{2 0 1 7}$ \\
\hline Индекс цен производителей промышленных товаров & 103,5 & 106,3 & 112,1 & 107,5 & 108,4 \\
\hline $\begin{array}{l}\text { Индекс цен производителей сельскохозяйственной } \\
\text { продукции }\end{array}$ & 102,7 & 114,1 & 108,5 & 101,8 & 92,2 \\
\hline $\begin{array}{l}\text { Рентабельность проданных товаров, продукции (работ, } \\
\text { услуг), процентов }\end{array}$ & & & & & \\
\hline $\begin{array}{l}\text { Сельское, лесное хозяйство, охота, рыболовство } \\
\text { и рыбоводство }\end{array}$ & 11,71 & 6,25 & 18,35 & 21,25 & 16,79 \\
\hline Добыча полезных ископаемых & 31,04 & 25,14 & 22,22 & 26,77 & 27,24 \\
\hline Обрабатывающие производства & 10,99 & 8,61 & 10,7 & 12,44 & 10,53 \\
\hline
\end{tabular}

Невысокая маржа отечественного АПК делает невозможным проведение широкомасштабной модернизации производства и внедрения инноваций.

\section{Заключение}

Введение продовольственного эмбарго и исключение внешней конкуренции должно было стать фактором развития сельского хозяйства. Однако снижение объемов импорта продовольствия с точки зрения продовольственной безопасности оказалось фикцией, поскольку импорт не был замещен отечественной сельскохозяйственной продукцией. В условиях снижающихся реальных доходов произошел сдвиг в потреблении - спрос увеличился 
по недорогим номенклатурным позициям продовольственных товаров, но более низкого качества.

Низкий уровень технического, технологического и инновационного развития АПК и ограничение импорта из США и стран ЕС обусловили снижение конкуренции на российском продовольственном рынке, что ожидаемо привело к давлению на цены. Девальвация рубля и отток инвестиций усугубили ситуацию. Все вместе это привело к увеличению цен на продовольствие на внутреннем рынке.

С точки зрения потребителя, как основного субъекта оценки агропродовольственной политики, результаты последней внушают мало оптимизма. Девальвация национальной валюты и политика жесткого протекционизма вместо того, чтобы стать катализатором для стремительного развития отечественного производства, привели к снижению реальных доходов и снизили «планку» доступности продовольствия для домохозяйств.

Необходимость процессов импортозамещения никто не оспаривает, но, помимо закрытия границ, требуется точечное воздействие на факторы роста - инвестиции, маркетинг, новую технику и технологии, и главное - срочное принятие мер по повышению внутреннего спроса.

Экспертная оценка уровня экономической безопасности по целому ряду показателей - обеспеченность продуктами питания, уровень реальных доходов населения, цены на продовольствие и др., демонстрируют отсутствие положительной динамики. Прогноз также не внушает оптимизма. Повышение пенсионного возраста, возросший НДС, высокая волатильность национальной валюты и стоимости углеводородов требуют разработки комплекса мероприятий по повышению экономической безопасности.

Таким образом, на сегодняшний день существует много вопросов, связанных не только с пересмотром показателей оценки доступности продовольствия, но и в целом - механизмов реализации Доктрины продовольственной безопасности и процессов импортозамещения. Можно с высокой долей вероятности утверждать, что, к сожалению, в краткосрочной и среднесрочной перспективе сохранится давление негативных факторов, которые продолжат снижать уровень благосостояния домашних хозяйств и все более отодвигать планку экономической доступности продуктов питания. 


\section{Литература}

Барсукова С. Ю. Аграрная политика России // Общественные науки и современность. 2017. № 5. С. 31-45.

Белова Т.Н. Ситуация на молочном «фронте» в период санкций // Экономист. 2015. № 4. С. 84-91.

Бикеева М.В. Статистический анализ дифференциации доходов и уровня бедности населения Российской Федерации // Экономические исследования и разработки: научно-исследовательский электронный журнал. Нижний Новгород: НОО «Профессиональная наука», 2018. № 2. 111 с.

Гайсин Р. С. Низкие доходы населения как фактор стагнации спроса и предложения на агропродовольственном рынке России // Вестник КазЭУ [Эл. pecypc]. URL: https://articlekz.com/article/13772 (дата обращения: 19.12.2018).

Глотова Е.А. Продовольственная безопасность России как гарант национальной безопасности // Право и политика. 2010. 30 нояб. № 11. С. 1919-1926.

Дятловская Е. Итоги четырех лет продовольственного эмбарго // Агроинвестор. 2018. 7 августа [Эл. ресурс]. URL: https:/www.agroinvestor.ru/analytics/ news/30210-itogi-chetyrekh-let-prodovolstvennogo-embargo/

Копеин В.В. Экономическая и продовольственная безопасность: новая реальность импортозамещения // Food Processing: Techniquesand Technology. 2016. Vol. 40. C. 126-134.

Самнер У. Протекционизм, или теория происхождения богатства от непроизводительного труда / Пер. с англ. Я. Новикова. С.-Петербург, 1893.

Самнер У., Новиков Я.А. Заблуждения протекционизма. М., Челябинск: Социум, Экономика, 2002. 254 с.

Шагайда Н., Узун В. Продовольственная безопасность: проблемы оценки // Вопросы экономики. 2015. № 5. С. 63-78.

Шагайда Н., Узун В., Шиикина Е. Как изменились потоки продовольствия в условиях эмбарго // Оперативный мониторинг экономической ситуации в России. Тенденции и вызовы социально-экономического развития. 2016. № 6. С. $18-22$.

Шевкунова E. С. Анализ уровня потребления продуктов питания // Научный журнал КубГАУ - Scientific JournalofKubSAU. 2014. № 101. URL: https:// cyberleninka.ru/article/n/analiz-urovnya-potrebleniya-produktov-pitaniya (дата обращения: 19.12.2018).

Статья поступила 20.03.2019.

Для цитирования: Конкина В. С. Экономическая доступность продовольствия в контексте проведения политики протекционизма // ЭКО. 2019. № 8. С. 103-117. DOI: 10.30680/ECO0131-7652-2019-8-103-117.

\section{Summary}

Konkina, V.S., Cand. Sci. (Econ.), Ryazan State Agrotechnological University of P.A. Kostychev, Ryazan

Economic Availability of the Food in the Context of Carrying out a Protectionism 
Abstract. In article one of aspects of food security at realization of protectionism in the agrofood sphere is considered. The analysis of availability of food in a section of decile groups is carried out. The lack of serious improvements in dynamics of an indicator in five years is noted. Reduction of import and lack of the external competition led to increase in prices for food products in domestic market. These factors at simultaneous decrease in real income led to negative consequences - raised a level of economic availability of food to households.

Keywords: food; economic availability; decile groups; import substitution; food security

\section{References}

Barsukova, S. Yu. (2017). Agricultural policy of Russia. Obshestvennye nauki i sovremennost'. No. 5. Pp. 31-45. (In Russ.).

Belova, T.N. (2015). The situation in the dairy market in the period of sanctions. Ekonomist. No. 4. Pp. 84-91. (In Russ.).

Bikeeva, M.V. (2018). Statistical analysis of income differentiation and poverty level of the population of the Russian Federation. Ekonomicheskie issledovaniya i razrabotki: nauchno-issledovatel'skii elektronnyi zhurnal. Nizhnii Novgorod: NOO Professional'naya nauka. No. 2. 111 p.

Dyatlovskaya, E. (2018). Results of four years of food embargo. Agroinvestor. (In Russ.) Available at: https://www.agroinvestor.ru/analytics/news/30210-itogichetyrekh-let-prodovolstvennogo-embargo/ (accessed 20.08.2018).

Gaisin, R.S. Low incomes of the population as a factor of stagnation of demand and supply in the agri-food market of Russia. Vestnik KazEU "Kazakh Economic Review”. (In Russ.) Available at: https://articlekz.com/article/13772 (accessed 19.12.2018).

Glotova, E.A. (2010). Food security of Russia as a guarantor of national security. Pravo i politika. No. 411. Pp. 1919-1926. (In Russ.).

Kopein, V.V. (2016). Economic and food security: a new reality of import substitution. Food Processing: Techniques and Technology. No. 40. Pp. 126-134. (In Russ.).

Samner, U. (1893). Protectionism, or the theory of the origin of wealth from unproductive labor. S.-Peterburg. $1893 \mathrm{p}$.

Samner, U., Novikov, Ya.A. (2002). Misconceptions of protectionism. Moscow, Chelyabinsk. Socium, Ehkonomika Publ. 254 p.

Shagaida, N., Uzun, V. (2015). Food security: the challenges of evaluation. Voprosy ekonomiki. No. 5. Pp. 63-78. (In Russ.).

Shagaida, N., Uzun, V., Shishkina, E. (2016). Changing flows of food under conditions of sanctions. Operativnyi monitoring ekonomicheskoi situacii v Rossii. Tendencii i vyzovy social'no-ekonomicheskogo razvitiya. No. 6. Pp. 18-22. (In Russ.).

Shevkunova, E. S. (2014). Analysis of the level of food consumption. Nauchnyi zhurnal KubGAU-Scientific Journal of KubSAU. No. 101. (In Russ.). Available at: https://cyberleninka.ru/article/n/analiz-urovnya-potrebleniya-produktov-pitaniya (accessed 19.12.2018).

For citation: Konkina, V.S. (2019). Economic Availability of the Food in the Context of Carrying out a Protectionism. ECO. No. 8. Pp. 103-117. (In Russ.). DOI: 10.30680/ECO0131-7652-2019-8-103-117. 